\title{
Review of the collective volume Siberian Identity in the Mirror of Literature: Tropes, Topoi, and Genres from the Nineteenth to Twenty-First Century (edited by N.V. Kovtun)
}

\author{
Jens Herlth* \\ University of Fribourg \\ Rue du Criblet 13, CH-1700 Fribourg, Switzerland
}

Received 30.01.2016, received in revised form 02.02.2016, accepted 24.02.2016

The present review provides a critical assessment of the book "Siberian Identity in the Mirror of Literature: Tropes, Topoi, and Genres from the Nineteenth to Twenty-First Century" edited by N.V. Kovtun.

Keywords: Siberian identity, Siberian text, traditionalism.

DOI: 10.17516/1997-1370-2016-9-3-675-677.

Research area: philology.

The volume Siberian Identity in the Mirror of Literature contains seventeen essays that approach varying aspects of Siberia as a territory, geographical space, and cultural construction; the range of topics includes socio-ideological, mythological, and religious ideas and motives in Russian literature from the last two centuries. The book consists of three parts.

Part I, "The Literary Image of Siberia from the Nineteenth to Twenty-First Century: From Ideology to Imagology," explores the genesis of the image of Siberia in the Russian cultural consciousness. Most of the authors adopt a sociohistorical perspective: the contributions in this section are thoroughly based on source material; the findings are carefully analyzed with recourse to the latest developments in the sociology of literature and history of culture. The general level of theoretical and methodological sophistication, along with the abundance of material, which is either new or shown for the first time from a highly innovative theoretical angle, make this section the strongest and the most interesting part of the book. The authors demonstrate how the image of Siberia emerged through the collision of the imagined space of a desert or a netherworld on the one hand, and the concrete geographical and social realities on the other. These articles analyze the ideological and epistemological preconditions as well as the side effects of the integration of Siberia into the common cultural and geographical space of Russia. The philological approach applied to historical documents reveals aspects that would have remained beyond the

(C) Siberian Federal University. All rights reserved

* Corresponding author E-mail address: jens.herlth@unifr.ch 
scope of purely historical analysis, such as the diversity of stylistic layers in travelogues and texts about Siberia.

Part II is devoted to the utopian, religious, and sometimes even esoteric concepts and myths reflected in the literature about Siberia or in Siberian literature in the proper sense. The focus is on the traditionalist and conservative tendencies which play such an important role in twentieth century Siberian literature. The authors also shed light on mythological and legendary concepts originating in folk beliefs and utopian ideas (Belovod'e, belovodskii metatekst, and similar motives). They convincingly highlight the origins and the continuing presence of a profoundly antimodernist attitude and worldview in what can duly be described as the "Siberian text" of Russian literature. It turns out, not so surprisingly though, that Valentin Rasputin and Viktor Astaf'ev are the writers who in many ways set the tone for the conservative and traditionalist tendencies which are so characteristic of late twentieth century and contemporary Siberian literature-or at least for its image that is widely shared by readers and researchers in the rest of Russia and beyond.

Astaf'ev's works especially serve as the constant point of reference and even as a kind of ideological bottom line for most of the articles in Part III; here, the authors examine specific aesthetic and literary aspects of the topos Siberia in the works of various Siberian writers (apart from Astaf'ev and Rasputin, these are Vasilii Shukshin, Aleksei Varlamov, and Galina Klimovskaia). Despite the apparent diversity of the discussed authors and works, the essays in this section allow us to detect certain leitmotifs and the invariants of the "Siberian text." They also delineate the common denominator of the ideological position that most of the authors discussed here seem to share, which consists of a penchant for an authentic and pure life unspoiled by any harmful external influences in the splendid isolation of the immeasurable Siberian space. The inevitable paradoxicality and inconsistency of this position is for me one of the most interesting outcomes of the book. One of the most intriguing articles from both the methodological and the thematic point of view is Mika Perkiomaki's "The River as the central ecological metaphor in "The Tsar Fish' by V. Astaf'ev." The author demonstrates the productivity of an ecocritical approach to Russian literature (however, I cannot agree with the conclusive statement that the "ecological consciousness" in the West emerged "on the basis of the ecocritical movement in literary criticism," it would be more appropriate to assume that what we know today as ecocriticism was a consequence and not the cause of the environmental movement in the Western societies of the 1960s).

Unfortunately, not all essays meet the generally high standard of theoretical and methodological sophistication. At times, one encounters terminological expressions or phrases which are unusual or uncommon for the academic style. For example, in "Eschatological Topics in Late Twentieth Century Siberian Prose" we find such expressions as "ontological core of national mentality," "psycho-mental characteristics of a Russian person," "dominants of the spiritual evolution of the world and the human being," and "national artistic instinct" (whatever these are supposed to mean). Unfortunately, the author does not provide any explanations or theoretical foundations for these vague and ideologically biased formulas. The article entitled "On the Question of the Methodology of the Study of Local [...] Literary Metatexts [...]" shows similar deficits. It goes without saying that the aspects of national identity or even mentality deserve attention in the framework of a project focused on Siberian literature, all the more as the crucial role of the Siberian topos in the context of Russophile ideas and sentiments has been so 
convincingly shown by the authors of the volume. However, the discussion of these concepts is not always conducted on the proper theoretical and conceptual level.

These critical remarks concern only a few of the articles collected here and they do not put into question the generally high scientific value of the book. The discussed topics are important not only for Siberian literature (or literature on and about Siberia), but also for a nuanced and context-sensitive understanding of Russian culture as a whole (questions of regionalism, the relation between center and periphery, the role of the province and provincial topoi, and the discontents of modernity and modernization). It is especially intriguing to see that, in Siberian literature, the very project of the modernizationand let us not forget that this implied also the colonization-of Siberia turned into a harsh rejection of everything that is economically and socially "modern." From this perspective, Siberian literature, at least in its main currents, can be seen as an essential component in the general flow of conservative and traditionalist attitudes in Russian literature and intellectual life of the late twentieth century. The present book will undoubtedly be of high interest for both specialists in the field as well as for any reader interested in the history of Russian culture and literature.

\title{
Рецензия на монографию
}

«Сибирская идентичность в зеркале литературного текста:

тропы, топосы, жанровые формы XIX-XXI веков»

(ответственный редактор Н.В. Ковтун)

\author{
Йенс Херльт \\ Фрибургский универстет \\ Ruе du Criblet 13 , СН-1700 Фрибург, Швейиария
}

В данной рецензии критически рассматривается монография «Сибирская идентичность в зеркале литературного текста: тропы, топосы, жанровые формы ХІХ-ХХ веков (отв. ред.: H.В. Ковтун).

Ключевые слова: сибирская идентичность, сибирский текст, традиционализм.

Научная специальность: 10.00.00 - филологические науки. 